\title{
Level vulnerability damage of pavement using Pavement Condition Index method
}

\author{
Siti Nurjanah Ahmad ${ }^{1, *}$, Tri Harianto ${ }^{1}$, Lawalenna Samang ${ }^{1}$, and Muralia Hustim ${ }^{1}$ \\ ${ }^{1}$ Hasanuddin University, Civil Engineering Department, Makassar, Indonesia
}

\begin{abstract}
This study aims to assess the vulnerability of road pavement damage using the Pavement Condition Index (PCI) method, including the direction of handling pavement road damage. Assessment of the level of road surface damage is based on the type of damage, the degree of damage, and amount of damage. Field observations and surveys were conducted on several Collector roads in Kendari. The mean PCI score as an indicator of damage to the Mokodompit road segment shows moderate damage conditions with a mean the value PClaverage $=53$ and surface damage area $=34.419 \%$ and the countermeasures according to the Bina Marga Standard recommend patching and adding pavement layers. Assessment of vulnerabilities Manunggal road damage indicates moderate damage to the value PClaverage $=49$ With the extent of surface damage $=34,419 \%$ and the response according to Standard by filling a crack with a mixture of liquid asphalt and sand.
\end{abstract}

\section{Introduction}

Road transport infrastructure plays an important role in supporting all human activities, the availability of adequate road network and able to connect the flow of transportation of goods and services more efficient and cheaper than other areas to enter into the city or vice versa. And the increase of traffic volume in each road segment is not accompanied by the addition of road length. Until now, Indonesia has only 296,968 km of road length (Minister of PUPR Basuki Hadimuljono, 2016), on the other hand the total road damage in Indonesia along $1,300 \mathrm{Km}(2016)$ is a condition of vulnerable road damage. This is due to several physical factors / structures, environmental factors, social, and economic factors that badly affect the efforts to prevent and overcome the damage paved roads.

Similarly, the state of highways in Kendari city in post-flood 2013 and 2017 many broken collector roads, among others, on the road along the road Mokodompit $2.3 \mathrm{Km}$ and, among others, on the road along the road Mokodompit $2.3 \mathrm{Km}$ and Manunggal road along the $1.6 \mathrm{~km}$ suffered damages, including mild or severe damageThe road damage is quite disturbing the smooth flow of traffic there, head towards the city of Kendari and vice versa. The cause of pavement damage on this road segment is due to poor subgrade, excessive vehicle loads, unfavorable climatic influences (the amount of rainfall), Road materials that do not meet established standards, poor implementation of work and unavailability of drainage on the left and right side of 2 (two) road segments.

* Corresponding author: nurjanaharifuddin@gmail.com 
Observing the strategic issues of road pavement damage, this study aims to assess the vulnerability of pavement damage by applying the method Pavement Condition Index and seek guidance for handling the damage of pavement layer and provide scientific input to local government especially related technical institution, so that in the implementation of repair of road damage will get more optimal result. In this study, we specifically surveyed and assessed the damage of pavement on the type of crack damage, wavy, decreased road shoulder, transverse and lengthwise damage, damage caused by water puddle and pothole damage.

\section{Literature review}

Road infrastructure in all areas will suffer damage, disturbance or deterioration of the condition, its quality when used to serve the activities of transporting people (passengers) or goods and services [1]. It is very necessary for pavement construction handling well, especially bending Pavement construction, including the building of new pavement or road improvements should be handling maintenance / rehabilitation periodically. In this condition the ability of the subgrade to support the load can be said to be very small. While the vehicle will still pass, due to the burden of vehicles pressing the surface of the road then there is release of the bond between the grains on the ground, and will cause the surface of the road to be broken and disappear. Well this is the initial process of road damage. Therefore almost every rainy season will appear many roads are damaged, ranging from a small hole to a very large hole. This results from an imperfect drainage condition.

According Sukirman [2] generally damage pavement effect to the road construction is not only caused by one factor, but a combination of many factor that are interconnected. The damage may be caused by:

1. Traffic, that can be an increase in load and load repetition and fatigue cracks load, resulted in layers of asphalt as well as deformation at all levels

2. Water can come from rain water and road drainage system is not good.

3. Pavement construction materials caused by the nature of the material it self or can be caused by a processing system that is not good.

4. Climate because Indonesia has tropical climate, where air temperature and rainfall are generally high, which can be one cause of road damage.

5. Unstable ground ground conditions caused by poorly implemented systems, or caused by subgrade poorly ground nature.

6. The compaction process over the underlying soil layers.

7. Damage to the pavement can occur due to vehicle load, on each layer of pavement voltage and strain occur.

\subsection{Concept pavement condition index ( $\mathrm{PCl})$}

To determine the value of the Pavement Condition Index is the level of pavement surface conditions and Measure the usefuly of function referring to the conditions and damage to the pavement surface. PCI was developed to provide an index of pavement structure integrity and its surface layer conditions. The damage data obtained can provide information on the causes of damage and whether the damage is related to the load or climate. By conducting periodic condition surveys, the pavement condition information can be useful for predicting future road pavement performance, but can also be used as a more detailed and focused measurement input. By looking at various types of damage to the pavement construction, the Pavement Condition Index method classifies the types of pavement damage as follows: 
a) Deformation Damage is wavy damage, groove, collapse, sungkur, fluffy, bumps and descend.

b) Cracked Damage is the longitudinal, transverse, diagonal, block and crocodile damage.

c) Damage to surface texture is damage to loose granules, bledding, slippery aggregates, and exfoliation.

d) Damage to the pothole is damage to patches and railroad crosses.

e) Damage at the edge of the pavement is damage; Edge crack/break and decline shoulder.

This PCI method is a numerical index whose value ranges from 0 to 100 . A value of 0 indicates that the pavement is very damaged and the value 100 indicates perfect pavement. This PCI method is based on visual pavement condition survey results by looking at the type of damage, level of damage, and size identified during the survey of the condition. The degree of damage used in the calculation of the Pavement Condition Index method is low severity level (L), medium severity level $(M)$, dan high severity level $(H)$.

Table 1 Relationship between PCI value and road conditions

\begin{tabular}{|c|c|}
\hline Value PCI & Damage Conditions \\
\hline $0-10$ & failer \\
\hline $11-25$ & Very Poor \\
\hline $26-40$ & Poor \\
\hline $41-55$ & Fair \\
\hline $56-70$ & Good \\
\hline $71-85$ & Very Good \\
\hline $86-100$ & Excellent \\
\hline
\end{tabular}

\subsection{Assesment pavement condition index (PCl)}

In analyzing road damage by PCI method is done by sequential way as follows [3-9]:

\subsubsection{Density}

Density is the percentage of area or total length of one type of damage to the total width or length of the road section measured in meters. Thus, the damage density can be expressed by the Equation Value equation (Deduct Value, DV).

The formula looks for density values:

$$
\begin{aligned}
& \text { Density }=A d / A s \times 100 \% \text { Atau } \\
& \text { Density }=L d / A s \times 100 \%
\end{aligned}
$$

Where :

Ad $=$ Total damage area for each level of damage $\left(\mathrm{m}^{2}\right)$

$\mathrm{Ld}=$ Total length of damage type for each level of damage (m)

As $=$ The total area of the segment unit $\left(\mathrm{m}^{2}\right)$ 


\subsection{Reduced value (DV)}

The Reduction Value is a deduction value for each type of damage obtained from the density relation curve and the severity of the damage, is Low (L) is the degree of minor damage, medium (M) Moderate damage rate, dan Hight $(\mathrm{H})$ high levels of damage.

\subsubsection{Total deduct value (TDV)}

Total Deduct Value (TDV) is the total value of the individual Reductions for each type of damage and the extent of damage existing in a research unit.

\subsubsection{Finding Value $q$}

The requirement to determine the value of $\mathrm{q}$ is determined by the amount of the individual Reducer value greater than 5 in each segment of the road segment under study.

\subsubsection{Calculating value correct deduct value}

CDV value can be sought after the value of $\mathrm{q}$ is known by summing the Reduce value Further deducting the amount of the subtraction value in the graphic image CDV corresponds to the value of q obtained.

\subsubsection{Calculating the value of pavement conditions}

After the CDV is obtained, the PCI for each sample unit is calculated using the equation:

$$
P C I s=100-C D V
$$

The PCI value of pavement as a whole on certain road segments is:

$$
P C I f=\sum P C I(s)
$$

Where :

$\sum P C I(s)=$ PCI for each segment unit

$\mathrm{CDV}=\mathrm{CDV}$ of each sample unit.

PCIf $=$ Value PCI average of all research areas.

PCIs = Value PCI For each sample unit

$\mathrm{N} \quad=$ Number of sample units

\subsubsection{Corrected deduct value (CDV)}

Dikoreksi Deduct Value (CDV) Obtained from the curve of the relationship between the value of TDV with the value of CDV with the selection of curve curve in accordance with the number of individual values of deduct value that has a value greater than 2 .

\subsubsection{Classification of pavement quality}

Value of (PCI) for each research unit can be known pavement unit quality pavement segment based on certain condition that is excellent, very good, good, fair, poor, very poor and failed [10]. 


\subsection{Standard of handling of road damage}

The handling for road damage in this study is guided by the Road Maintenance Manual [11] issued by the Directorate of Highways and the Routine Maintenance Manual for National Roads and Provincial Road Volume II Title Standard Repair Method [12] issued by the Directorate of Highways. Both manuals describe all types of damage, causes of road damage, the process of handling road damage and road maintenance processes.

\section{Result}

\subsection{Assessment rate of road damage}

Based on road damage assessment using PCI method on Mokodompit road and Manunggal road segment with the formula: PCI - 100 - CDVmax obtained average PCI value on both roads there is difference of value of road damage condition in table 2 as follows:

Table 2. Result of calculation of road damage condition by PCI method

\begin{tabular}{|c|c|c|c|c|c|}
\hline \multirow{2}{*}{ No } & \multirow{2}{*}{ Station (m) } & \multicolumn{2}{|c|}{ Mokodompit Road } & \multicolumn{2}{|c|}{ Manunggal Road } \\
\hline & & Value PCI & Road Condition & Value PCI & kondisi jalan \\
\hline 1. & $0+000-0+100$ & 38 & Poor & 48 & Fair \\
\hline 2. & $0+100-0+200$ & 90 & Perfect & 68 & good \\
\hline 3. & $0+200-0+300$ & 25 & Poor & 40 & Fair \\
\hline 4. & $0+300-0+400$ & 42 & Fair & 32 & Poor \\
\hline 5. & $0+400-0+500$ & 81 & Very Good & 56 & Good \\
\hline 6. & $0+500-0+600$ & 38 & Poor & 41 & Poor \\
\hline 7. & $0+600-0+700$ & 68 & Good & 36 & Poor \\
\hline 8. & $0+700-0+800$ & 88 & Perfect & 35 & Poor \\
\hline 9. & $0+800-0+900$ & 65 & Good & 78 & Very Good \\
\hline 10. & $0+900-1+000$ & 20 & Very Poor & 65 & Good \\
\hline 11. & $1+000-1+100$ & 78 & Very Good & 36 & Poor \\
\hline 12. & $1+100-1+200$ & 66 & Good & 31 & Poor \\
\hline 13. & $1+200-1+300$ & 35 & Poor & 69 & Good \\
\hline 14. & $1+300-1+400$ & 51 & fair & 57 & Good \\
\hline 15. & $1+400-1+500$ & 40 & Fair & 70 & Good \\
\hline 16. & $1+500-1+600$ & 80 & Very Good & 24 & Poor \\
\hline 17. & $1+600-1+700$ & 30 & Poor & & \\
\hline 18. & $1+700-1+800$ & 34 & Poor & & \\
\hline 19. & $1+800-1+900$ & 68 & Good & & \\
\hline 20. & $1+900-2+000$ & 34 & Poor & & \\
\hline 21. & $2+000-2+100$ & 47 & Fair & & \\
\hline 22. & $2+100-2+200$ & 51 & Fair & & \\
\hline 23. & $3+200-2+300$ & 40 & Fair & & \\
\hline & amount & 1209 & & 786 & \\
\hline \multicolumn{6}{|c|}{$\begin{array}{l}\text { Average PCI value for road. Mokodompit is }=\sum P C I / n=1209 / 23=52,56=53 \\
\text { With condition value }=\text { Fair }\end{array}$} \\
\hline $\begin{array}{l}\text { Ave } \\
\text { Wit }\end{array}$ & $\begin{array}{l}\text { e PCI value for } \boldsymbol{r o a} \\
\text { ndition value }=\boldsymbol{F} \boldsymbol{c}\end{array}$ & anunggal is & $\sum P C I / n=786 / 16$ & $49,125=49$ & \\
\hline
\end{tabular}




\subsection{Types and percentage of road damage level}

Type of damage that occurred on the road Mokodompit damage pothole with damage area of $39.625 \mathrm{~m} 2$ with the percentage of damage $34.419 \%$, alligator cracking cracks with damage area of $14.875 \mathrm{~m} 2$ with the percentage of damage $12.921 \%$, patches with an area of damage of $8,688 \mathrm{M} 2$ with damage percentage $7,547 \%$, roadside crack with damage area equal to $11.000 \mathrm{~m} 2$ with percentage of damage $9,555 \%$, weathering and loose grane with damage area $3,75 \mathrm{~m} 2$ with damage percentage $3,257 \%$, city-box crack with damage area 13 , $75 \mathrm{~m} 2$ with damage percentage 11,943\%, and damage of rutting with damage area equal to $23,438 \mathrm{~m} 2$ with damage percentage $20,359 \%$. But the most dominant type of damage is hole damage (pothole).

As for the road of Manunggal there is damage to the type of hole (pothole) with damage area of $39,625 \mathrm{~m} 2$ with damage percentage $34,419 \%$, crack lengthwise or transverse with damage area equal to $39,625 \mathrm{~m} 2$ with damage percentage $34,419 \%$, alligator cracking $14,875 \mathrm{~m} 2$ with damage percentage $12,921 \%$, road shoulder damage with damage area equal to $39,625 \mathrm{~m} 2$ with percentage of damage $34,419 \%$, patch with damage area $8,688 \mathrm{~m} 2$ with damage percentage $7,547 \%$, crack edge / side of road with damage area equal to $11.000 \mathrm{~m} 2$ with percentage $9,555 \%$ damage, rutting with damage area equal to $23,438 \mathrm{~m} 2$ with damage percentage $20,359 \%$ and damage of basin with damage area equal to $39,625 \mathrm{~m} 2$ with damage percentage $34,419 \%$, but the most dominant type of damage is damage crack length / transverse.

Table 3. Result of calculation of road damage condition by PCI method

\begin{tabular}{|c|c|c|c|c|c|}
\hline \multirow[b]{2}{*}{ No } & \multirow[b]{2}{*}{ Type of Damage } & \multicolumn{2}{|c|}{ Mokodompit Road } & \multicolumn{2}{|c|}{ Manunggal Road } \\
\hline & & Area $(\mathbf{m} 2)$ & $\begin{array}{c}\% \\
\text { kerusaka } \\
\mathbf{n}\end{array}$ & Area $(\mathbf{m} 2)$ & $\begin{array}{c}\% \\
\text { kerusakan }\end{array}$ \\
\hline 1. & Hole (pothole) & 39,625 & 34,419 & 13,87 & 19,403 \\
\hline 2. & Cracks extend and transverse & ---- & ---- & 15,00 & 20,984 \\
\hline 3. & Alligator cracking & 14,875 & 12,921 & 14,55 & 20,354 \\
\hline 4. & Path / descent of road shoulder & ---- & ---- & 5,75 & 8,044 \\
\hline 5. & $\begin{array}{c}\text { Patch } \\
\text { Roadside / side fracture }\end{array}$ & 8,688 & 7,547 & 7,313 & 10,230 \\
\hline 6. & Roadside / side fracture & 11,000 & 9,555 & 3,25 & 4,547 \\
\hline 7. & Weathering and granular discharges & 3,75 & 3,257 & ---- & ---- \\
\hline 8. & Crack the boxes & 13,75 & 11,943 & ---- & ---- \\
\hline 9. & rutting & 23,438 & 20,359 & 9,75 & 13,640 \\
\hline 10. & Basin & ---- & ---- & 2,00 & 2,798 \\
\hline & Amount & 115,126 & 100 & 71,483 & 100 \\
\hline
\end{tabular}

On both sides of the road that suffered the most severe damage and need serious attention, so that damage does not increase if not quickly repaired. Damage to both roads causing inconvenience for motorists who use the road, either damaged holes light, medium or heavy hole. This occurs as a result of the development of other types of damage that are not immediately addressed, the effects of weather (especially rain/ flood) and vehicle traffic that exceeds the implied load that accelerates the formation of holes. 


\section{Extent and type of damage}

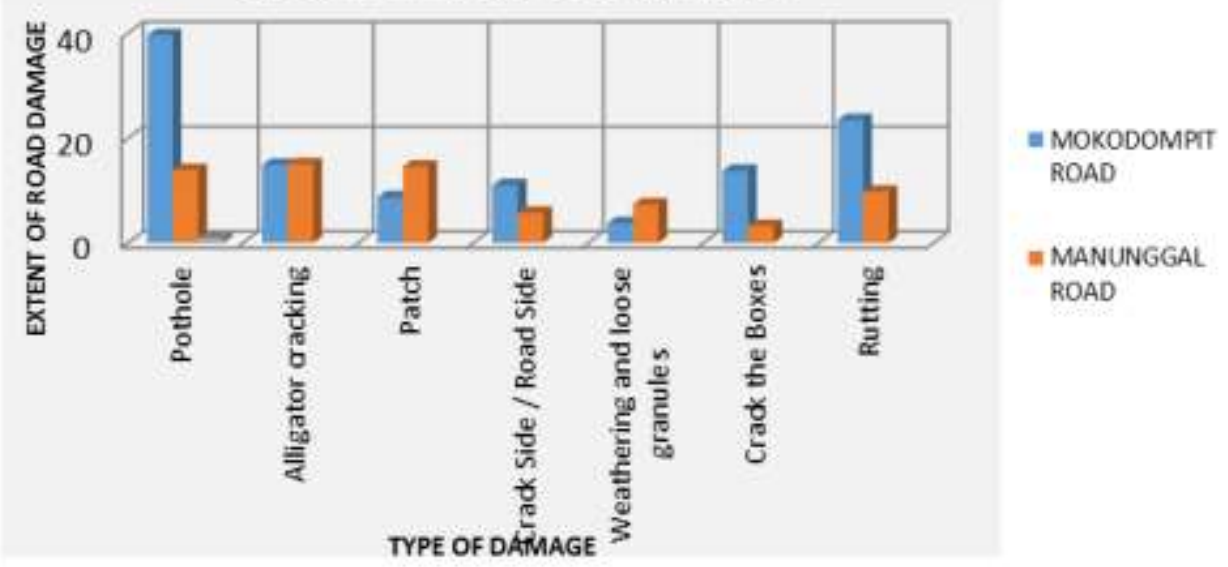

Fig.1. Area and type of road damage

\subsection{Direction for improvement and handling of road damage}

Based on the analysis with PCI method, the condition of the road pavement of each segment unit obtained in the field can be used to know the most vulnerable road pavement damage and to determine the priority of handling the damage by prioritizing the damage handling on the road pavement which has a pavement damage condition value which Greatest.

On Mokodompit road, the most vulnerable type of damage is damage of hole 39,625 m2 with damage percentage $34,419 \%$, repair effort or handling according to Bina Marga regulation (1993) the corrective action is by hole patching and addition of pavement layer. While on Manunggal road type of the most vulnerable damage is the damage of crack lengthwise/transverse with damage area equal to $39,625 \mathrm{~m} 2$ and percentage of damage $34,419 \%$ improvement effort done by filling gap with liquid asphalt mixture and sand.

\section{Conclusion}

Based on the analysis results obtained conclusion as follows:

1. The average PCI score as an indicator of damage to the Mokodompit road segment showed moderate damage conditions with an average PCI value $=53$ and surface damage area $=34.419 \%$ and the Assessors of susceptibility to road damage indicated moderate damage with a mean PCI value $=49$ with area surface damage $=34.419 \%$.

2. Countermeasures for Mokodompit road according to Bina Marga standard recommends to patch and add pavement layer and handling for Manunggal road by filling crack gap with liquid asphalt mixture and sand.

3. The practical implications of assessing the vulnerability level of pavement damage on collector roads become a consideration in the formulation of the improvement and maintenance of urban collector roads. 


\section{References}

1. Bustan, B., Sammang, L., Nurali, Ramli, I. Risk level assessment on road construction's contractors using cultural-professionalism based approach. International Journal of Civil Engineering and Technology. (2016)

2. S, Sukiman. Bending Pavement Highway. Bandung: Nova. (1999)

3. Fadly, Ahmad. Evauasi level of damage to the road surface of your contentpaguyuman based Pavement Condition Index (PCI) method. Position ATPW seminar. Surabaya (2013)

4. Directorate of Highways, 1983. Routine Maintenance Manual for National and Provincial Roads Volume II Title of Standard Improvement Method No. 002 / T / Bt / 1995. Dep. Pek. General. Jakarta.

5. Directorate of Technical Affairs. Survey of paved road conditions in urban areas, urban governance and rural governance department of residential and infrastructure Jakarta area. (2002)

6. Amin, Khairi. Evaluation of type and extent of damage by using PCI method (Case study on Soekarno-Hatta Street). Journal of Bengkalis State Polytechnic. (2012)

7. Febry, Noval T. Evaluate the level of road damage using the method of pavement condition index (pci) case study Jl.Purwekerto-Ajibarang Kab. Banyuwangi. National Symposium on Applied Technology (SNTT) to-4. (2016)

8. B, Margareth E. Comparison of Bina Marga Method and PCI Method (Pavement Condition Index) in the assessment of Pavement Conditions. (2015)

9. A, Suswandi. Evaluation of road damage with PCI method (Pavement Condition Index) to support decision making (Case Study: South Ring Road of Jogyakarta). Civil Engineering Forum Magazine No. XVIII, September 2008. (2008)

10. Hustim, Muralia. Study of development of road network of regency in pinrang district of south sulawesi based on Multi Criteria Analysis Method. Tri Sakti University, Jakarta.(2012)

11. Directorate of Highways. Road Maintenance Manual No.03 / MN / B / 1983. Jakarta. (1983)

12. Directorate General of Highways. Technical Guidance Survey of Road Engineering Planning No. 013 / T / Bt / 1995. Dep. Pek. General. Jakarta. (1995) 


\begin{tabular}{|c|c|c|c|c|c|c}
\hline Time & $\begin{array}{c}\text { Movement of } \\
\text { Vehicles from } \\
\text { Land Use } \\
\left(\mathbf{V}_{\mathbf{i}}\right)\end{array}$ & $\begin{array}{c}\text { Continuous Flow } \\
\text { Movement } \\
\left(\mathbf{V}_{\text {eksternal }}\right)\end{array}$ & $\begin{array}{c}\text { Total } \\
\text { Volume } \\
\text { Movement }\end{array}$ & Capacity & $\begin{array}{c}\text { Ratio } \\
\text { V/C }\end{array}$ & LOS \\
\hline $06.00-07.00$ & 11739 & 5663 & 17402.0 & 5023.2 & 3.46 & $\mathrm{~F}$ \\
\hline $07.00-08.00$ & 8815 & 5887 & 14701.5 & 5023.2 & 2.93 & $\mathrm{~F}$ \\
\hline $08.00-09.00$ & 8199 & 5093 & 13292.1 & 5023.2 & 2.65 & $\mathrm{~F}$ \\
\hline $09.00-10.00$ & 7977 & 4663 & 12640.2 & 5023.2 & 2.52 & $\mathrm{~F}$ \\
\hline $10.00-11.00$ & 7970 & 4404 & 12374.1 & 5023.2 & 2.46 & $\mathrm{~F}$ \\
\hline $11.00-12.00$ & 7640 & 4037 & 11677.4 & 5023.2 & 2.32 & $\mathrm{~F}$ \\
\hline $12.00-13.00$ & 8047 & 3978 & 12025.2 & 5023.2 & 2.39 & $\mathrm{~F}$ \\
\hline $13.00-14.00$ & 8313 & 4008 & 12321.2 & 5023.2 & 2.45 & $\mathrm{~F}$ \\
\hline $14.00-15.00$ & 7887 & 4183 & 12070.0 & 5023.2 & 2.40 & $\mathrm{~F}$ \\
\hline $15.00-16.00$ & 7804 & 4386 & 12190.7 & 5023.2 & 2.43 & $\mathrm{~F}$ \\
\hline $16.00-17.00$ & 11553 & 4498 & 16051.1 & 5023.2 & 3.20 & $\mathrm{~F}$ \\
\hline $17.00-18.00$ & 12253 & 4866 & 17118.8 & 5023.2 & 3.41 & $\mathrm{~F}$ \\
\hline $18.00-19.00$ & 11777 & 4579 & 16355.9 & 5023.2 & 3.26 & $\mathrm{~F}$ \\
\hline $19.00-20.00$ & 7578 & 4040 & 11617.5 & 5023.2 & 2.31 & $\mathrm{~F}$ \\
\hline
\end{tabular}

